on the use of the table of the values of the thermic term -before-mentioned-and a supplementary note on devices to eliminate the influence of wind-pressure.

It may be stated that of the seven plates referred to as illustrating this work, six are wanting in the copy now under notice.

\section{ON A METHOD OF ESTIMATING THE STEADINESS OF ELONGATED SHOT WHEN FIRED FROM LARGE GUNS}

I $N$ Cctober last it was stated in the newspapers that "at the request of Lord Alcester," and in the presence of the Lords of the Admiralty, "comparative trials of a Krupp gun and a 6-inch breechloader took place greatly to the advantage of the former." . . . "The projectile used in the English weafon was 10o lb. with a $34 \mathrm{lb}$. charge, and that in the Krupp gun $64 \mathrm{lb}$. with a $14 \mathrm{lb}$. charge, the results from the latter being far in advance of the former." If this statement be exact, the matter calls for the most careful consideration. In such a case the superiority of the Krupp gun must have arisen either from the higher initial velocity, or from the greater steadiness imparted to the shot by the Krupp gun, or probably from both these causes combined. The comparative merits of these or any other guns could be very readily settled by well-known methods of experimenting, at the expense of little more than the cost of 5 to Io rounds of ammunition for each gun. There is no necessity for a repetition of the Armstrong and Whitworth competition, said to have cost some $30,000 l$.

Numerous experiments were made in this country in 1867-68 with guns of $3,5,7$, and 9 inches calibre, to determine the resistance of the air to the motion of both round and elongcted projectiles. Coefficients of resistance were then determined for all velocities between 900 f.s. and I700 f.s. Additional experiments were made in I 878-79 with elongated projectiles alone, which gave the coefficient of resistance $\mathrm{K}$ corresponding to all velocities between 430 f.s. and 2250 f.s. But after this report had been printed, which contained general tables for both time and space within the above-named limits of velocity, it was decided to have additional experiments made with both lower and higher velocities. The final report of these experiments was published in 1880 , which contained general tables for space and time for velocities between 100 f.s. and 2900 f.s. The values of $\mathrm{K}_{v}$ corresponding to the velocity $v$, as given in this report, will be hereafter referred to as the "tabular" values of $\mathrm{K}_{\%}$. The weight of a cubic foot of air was taken to be 534.22 grains.

In testing any new gun I would proceed, as in the above-named experiments, to measure the times occupied by the shot in passing over a succession of equal distances. These observations would readily give the velocity $v$ of the shot at any point of its path, and also the corresponding coefficient of resistance $\mathrm{K}_{v}$. Then according as the mean value of $\mathrm{K}_{v}$ derived from 5 to ro rounds, was found to be greater or less than the tabular value of $\mathrm{K}_{v}$, it would be evident that the gun on its trial gave a less or greater degree of steadiness than the average of the guns used in the experiments of $1867, \& c$.

Let us examine the relative value of these four guns in rounds where the middle velocity was about $\mathrm{I} 280 \mathrm{f} . \mathrm{s}$.

Rounds 6-12, I 24 and 126 were fired from the 3 -inch gun, with projectiles of $9 \mathrm{lb}$, giving for $\mathrm{K}_{1280}$ respectively the values I 36.5 , I I0.7,-, I I $4.5,118.2$, I $21^{\circ} 0$, I I $9^{\circ} 2$, III' 7 , and III. 2 ; the mean of which, II7.9, is 8.9 higher than $109^{\circ} 0$, the tabular value of $K_{1280^{\circ}}$. Consequently this gun falls below the average in steadiness very decidedly.

Rounds 164-168 were fired from a 5-inch gun with projectiles of $47.68 \mathrm{lb}$., giving for $\mathrm{K}_{1280}$ respectively the values I IO' $2,98^{\circ} 9,91^{\circ} \mathrm{O}$, IOI $^{\circ} 5$, and $97^{\circ} 9$; the mean of which, $99^{\circ} 9$, is therefore $9^{\circ} \mathrm{I}$ below ro ro, the tabular value of $\mathrm{K}_{3280}$.
Consequently these solid 5-inch shot had a very high degree of steadiness.

Rounds $148-153$ were fired from the same 5 -inch gun, but with hollow projectiles of $23.84 \mathrm{lb}$., giving for $\mathrm{K}_{1280}$ respectively the values $105^{\circ} \mathrm{I}, \mathrm{II}_{3} 4$, I0I 5 , $105^{\circ} 4$, 1077 , and $1020^{\circ}$; the mean of which, $105^{\circ} 9$, is $3^{\circ}$ I below $109^{\circ} 0$, the tabular value of $K_{1280}$. The steadiness of these shot was above the average, but inferior to that of the solid 5 -inch shot.

Rounds 97-IOI were fired from a 7-inch gun, with projectiles of $123.125 \mathrm{lb}$, giving for $K_{1300}$ respectively the values 109.8 , 118.7 , 108.6, II7 6, and II 75 ; the mean of which, $11_{4} 4$, is 5.8 greater than 108.6 , the tabular value of $\mathrm{K}_{1300}$. The 7 -inch projectiles were therefore deficient in steadiness.

Rounds 218-22I and 228 were fired from a 9-inch gun with projectiles of $250 \mathrm{lb}$. giving for $K_{1280}$ respectively the values $110^{\circ} 4,104 \%$, I26.0, II $80^{\circ}$, and $13 \mathrm{I}^{\circ} 2$; the mean of which, I 8.2 , is $9^{\circ}$ above the tabulated value $109^{\circ} 0$ of $\mathrm{K}_{1280}$. The 9 -inch shot were therefore very unsteady.

We thus arrive at the character of each of the experi mental guns from the error in $K_{v}$. In the 3 -inch gun the error was +8.9 : in the 5 -inch gun (solid shot), -9.1 ; in the 5 -inch gun (hollow shot), -3.1 ; in the 7 -inch gun, $+5^{\circ} 8$; and in the 9 inch gun, $+9^{\circ}$.

Some experiments were made with projectiles provided with various forms of heads in 1866 . Although the programme was never fully carried out, the rounds fired with hollow ogival-headed shot of one and two diameters were tolerably numerous. The two forms of shot were fired alternately, and gave the following values of $K_{1400}$.

\begin{tabular}{|c|c|c|c|c|c|}
\hline $\begin{array}{l}\text { Round } \\
\text { I4 }\end{array}$ & $\begin{array}{c}\text { One diameter } \\
108.6\end{array}$ & $\begin{array}{l}\text { Error } \\
+0^{\circ} .\end{array}$ & $\begin{array}{l}\text { Round } \\
\text { I5 }\end{array}$ & $\begin{array}{c}\text { Two diameters } \\
1088^{\circ}\end{array}$ & $\begin{array}{r}\text { Error } \\
+4^{.6}\end{array}$ \\
\hline 16 & II3.r & $+4 \cdot 6$ & 17 & - & - \\
\hline I8 & $109^{\circ} 6$ & $+I \cdot I$ & 19 & - & - \\
\hline 20 & $108 \cdot 0$ & -0.5 & $2 \mathrm{I}$ & 103.5 & $+0 \cdot 1$ \\
\hline 22 & $105 \cdot 3$ & $-3 \cdot 2$ & 23 & $104 \cdot 6$ & $+I \cdot 2$ \\
\hline 24 & 110 & $+I \cdot 6$ & 25 & $99^{\prime} \mathbf{I}$ & $-4 \cdot 3$ \\
\hline 26 & $108 \cdot x$ & -0.4 & 27 & ICO 8 & $-2 \cdot 6$ \\
\hline 28 & 108.4 & $-0 \cdot 1$ & 29 & 1030 & -0.4 \\
\hline 30 & 109.6 & $+I \cdot I$ & $3 \mathrm{I}$ & $104^{\circ} \mathrm{O}$ & to 6 \\
\hline \multirow[t]{2}{*}{32} & IO 44 & $-4 \cdot I$ & 33 & 104.2 & +0.8 \\
\hline & $1085^{\prime} 2$ & 16.8 & & $8 \longdiv { 8 2 7 ^ { \prime 2 } }$ & $8 \longdiv { \mathrm { I } _ { 4 } \cdot 6 }$ \\
\hline Means & $108 \cdot 5$ & 17 & Means &.$\overline{1034}$ & 1.8 \\
\hline
\end{tabular}

The tabular value of $\mathrm{K}_{1+00}$ is $104 \%$, which was derived from experiments made with ogival-headed shot struck with a radius of one diameter and a half. The unit of $\mathrm{K}$ in the above cases corresponds to about the $\mathrm{I} / 50,000$ of a second.

M. Krupp has recently circulated some tables which are based on coefficients, a little less than the tabular numbers above referred to, and about such as would have been obtained if I had used those coefficients only which were given by the most steady moving projectiles. Since 1868 there have been great improvements made in the manufacture of slow-burning powder, \&c., which may have tended to give increased steadiness to the shot, and thus to reduce the resistance of the air slightly. Still I do not think it desirable at present to reduce my coefficients sensibly, because in all my experiments the velocities have been determined during the motion of the shot just after it had left the gun. But when the range of the shot is considerable, the direction of the axis of the shot must become inclined to the direction of the motion of the shot, and this must increase the resistance of the air. If it was thought desirable to reduce the coefficients of resistance throughout any range in a particular case by $\frac{1}{2}$ th or ${ }_{1}^{2} \mathrm{t}$ th, $\&$ c., this could easily be effected by multiplying $d^{2} \div \omega$ by $\left(1-\frac{1}{2}\right),\left(1-\frac{1}{10}\right)$, \&c. For heavy shot the range should be extended much beyond 500 yards

The pamphlet alluded to above is entitled "Table de Krupp pour le calcul des vitesses restantes horizontales et des durées de trajet des projectiles oblongs. Essen, 
I881." M. Krupp does not give any details of the experiments on which he professes to have founded his tables, or acknowledge any kind of assistance from any other author. He remarks that for a long time the resistance of the air was supposed to vary as $v^{2}$, then to depend upon two powers of $v$, ard afterwards to vary as $v^{3}$ or $v^{4}$ Experiments have shown that these so-called laws of resistance are not good for all velocities. "Cette expérience devait le faire paraître utile de trouver une nouvelle méthod pour le calcul des vitesses restantes" (p. I6). And again, "Un tel tableau pour différences de vitesse de $10 \mathrm{~cm}$. a été établi par l'usine Krupp au commencement de l'année 1880 " (p. i 8 ).

M. Krupp's tables are precisely the same as those that have been used in England since $187 \mathrm{I}$, except only that French replace English measures, and that a small reduc. tion of the English coefficients of resistance has been made throughout. Taking one of Krupp's examples (last page) I I $/ 6 / 79$, where $d=355 \mathrm{~mm}$. $=13^{\circ} 977$ inches ; $w=$ 525 kilos. $=1157^{\circ} 43$ lbs. ; commencing velocity $490 \mathrm{~m} . \mathrm{s}$. $=1607.64$ f.s. ; remaining velocity 415 m.s. $=136 \mathrm{I}^{\circ} 57$ f.s., at distance $2384 \mathrm{~m}$. $=782 \mathrm{I} \cdot 6 \mathrm{ft}$. ; weight of I cubic metre of air $=I^{2} 200$ kilos., M. Krupp finds from his table $411.8 \mathrm{~m} \mathrm{~s}$. for the remaining velocity instead of $415 \mathrm{~m} . \mathrm{s}$. given by his experiment. My table gives a remaining velocity of $405.7 \mathrm{~m}$.s. But supposing we reduce the coefficients of resistance in the proportion $99^{\circ} 9:$ I09 0 given by the experiments made with the 5 -inch gun (solid shot), then we obtain $412^{\circ} \circ \mathrm{m} . \mathrm{s}$. for the required remaining velocity, which is nearly the same as $41 \mathrm{I} .8 \mathrm{~m} . \mathrm{s}$. obtained by the use of Krupp's table. Again, taking the experiment $6 / 8 / 79$ with a projectile $400 \mathrm{~mm}$. in diameter, commencing with a velocity $533^{\circ} 4 \mathrm{~m} . \mathrm{s}$., M. Krupp finds a remaining velocity of $447^{\circ} \mathrm{Om}$.s. by the use of his table, while I obtain $440^{\circ} 4 \mathrm{~m} . \mathrm{s}$, and $443.8 \mathrm{~m} . \mathrm{s}$. is given as the result of experiment. But if I reduce all my coefficients as before in the ratio $99^{\circ} 9: 109^{\circ}$, then my table gives $447: 4 \mathrm{~ms}$, as the remaining velocity, which agrees with M. Krupp's calculations. Hence it appears that M. Krupp claims by these tables that his guns of 1880 , on the average, give a degree of steadiness about equal to that given by the best of the four English experimental guns used in I867-68. I have not much confidence in the accuracy of velocities measured at a distance of near one mile and a half from the gun by an instrument not specified, but I have used these data as a means of indicating to what extent the tables give different results. As a test of the tables I should much prefer a careful determination of the commencing velocity of the shot, and the time of flight to some known distant point, where all the times were measured by a single instrument.

I or further information I beg leave to refer M. Krupp to (1) "Tables of Remaining Velocity, Time of Flight and Energy of various Projectiles, \&c." I871; (2) to the Proceedings of the Royal Artillery Institution, Woolwich, September I87I, p. 382 , \&c. ; (3) Ib., April 1872, p. I, \&c. ; (4) Ib., December 1877, p. 250 , \&c. ; (5) "Treatise on the Motion of Projectiles, \&c.," I 873 ; (6) "Principles of Gunnery," by Major Sladen, R.A., I879; (7) " Handbook for Field Service" (R.A.), r 878 ; (8) "The Construction of Ordnance, \&c.," p. 359, \&c., I877 ; (9) "Reports on Experiments, \&c., 84/B/2853," 1879; (10) "Final Report on Experiments, \&c., 84/B/2909," I 880 ; and (II) and (I2) "Manual of Gunnery for H.M. Fleet," 1880. And since that date my "General Tables" have been reprinted in four different books.

Since the above was written, I have noticed that the introducer of the Navy Estimates, 1884, remarked:"The old breech-loader had been found to be of no more use than a muzzle-loader, and the Government had adopted a gun twice as long as the old form of breechloader." I always understood that the profitable use of the new slow-burning powder required a long barrel, and th it the bretch-loading arrangement was introduced be- cause it permitted the use of a longer barrel on shipboard than could be employed with muzzle-loading. March 22

FRANCIS BASHFORTH

\section{THIRD NOTE ON THE ELECTRICAL RESIST ANCE OF THE HUMAN BODY}

$\mathrm{T}$ two previous communications last year, I showed that the amount of this important basis of rational electrotherapeutics had been enormously overstated. Since then I find it given in the new edition of Rosenthal's "Elektricitätslehre," published in the current year, as about $5000 \mathrm{ohms}$, and, to my surprise, so competent an observer as my friend Prof. Dolbear, in Lockwood's "Handbook of Electric Telegraphy," states it vaguely as from 6000 to 10,000 ohms. On the other hand, Count Du Moncel, in his paper on the conductivity of imperfect conductors in the Annales de Chémie et de Physique, vol. x., I877, approaches more nearly to the real value in stating it from wrist to wrist to vary from 350 to 220 kilometres. This is probably the Swiss unit given in Clark and Sabine's tables as equal to 10.42 ohms or thereabouts. Both Rosenthal and Du Moncel furnish internal evidence that their excessive estimates were due to imperfect contact through the skin: for the former speaks of using fifty chromic acid elements of two volts E.M.F. each; whereas the current from this large battery, with proper contact, would be utterly unbearable to the patient, if not dangerous. The highest current I have seen employed was from twenty-two of these cells through less than 2000 ohms resistance. It was done against my advice, and produced a large carbuncular boil at the nape of the neck, where the negative pole was applied. I have since then completely modified my method of making the skin contacts, and no similar accident has occurred.

Even with a far smaller current, namely, that of eight Daniell cells and small platinum electrodes, of which the size is accurately given, namely, $4 \frac{1}{2}$ by $3 \mathrm{~cm}$. (roughly, the length of two shillings side by side, and the breadth of a florin), Du Moncel produced a similar though much more serious accident. The current was passed at intervals for an hour and a half from wrist to wrist, the patient being a lady, and afterwards for shorter periods in the opposite direction. "On withdrawing the electrodes," says the writer, "to my great astonishment I found, on the parts of the wrists where my electrodes had been applied, very pronounced scars resembling burns produced by an acid or a caustic. These scars, to the number of three at the negative pole, were large and deep. At the positive pole they were very small, and thirty-two in number. During the first two days after the experiment no inflammation supervened, but on the third day it began about the negative scars, and it was necessary to have recourse to poultices, which were kept up for a month ; even then the sloughs were not detached." It is satisfactory to find that no permanent harm was done ; but it is evident that the excessive resistance recorded, amounting at times to $3500 \mathrm{ohms}$, was mainly due to this cause. It is perhaps not to be wondered at that the scientific Count should have relinquished this branch of his investigation.

With hands soaked in strong brine, and then enveloped in a thickness of flannel wetted with the same solution, bandaged surgically over this with a spiral strip of lead at least $30 \mathrm{~cm}$. long and $5 \mathrm{~cm}$. broad, no local accident has ever occurred to me, nor has any local pain been mentioned. But with ten bichromate cells in good order the shock felt at making and breaking circuit has often been considerable. Indeed my tall and athletic clinical clerk, Mr. Shackel, who kindly consented to act as a resistance, noticed that, when being tested from foot to hand (in his case a length of 7 feet) with 1027 ohms resistance, the opposite side of the body was jerked at these instants. In all recent experiments I have never exceeded this E.M.F., 